\title{
EDUKASI PENERAPAN PROGRAM “GOOD MANUFACTURING PRACTICES” (GMP) DAN KEAMANAN PANGAN UNTUK PENGEMBANGAN KAMPUNG TEMPE
}

\author{
Ambar Fidyasari ${ }^{1}$, Sentot Joko Raharjo ${ }^{2}$ \\ ${ }^{1,2}$ Akademi Analis Farmasi dan Makanan Putra Indonesia Malang \\ e-mail: fidyafloss@gmail.com
}

\begin{abstract}
ABSTRAK
Tempe merupakan salah satu produk pangan nabati yang memiliki nilai gizi cukup tinggi. Di desa Beji kota Batu merupakan salah satu tempat pusat pengrajin tempe. Tempe yang dihasilkan merupakan tempe yang khas daerah tersebut, namun kendala yang dihadapi pengrajin belum menerapkan pentingnya Good Manufacturing Practices (GMP) dan keamanan pangan sehingga tempe yang dihasilkan kurang konstan.Adanya potensi kampung tempe tersebut, maka dilakukan program edukasi kepada para pengrajin tempe. Tujuan utama dalam program pendampingan ini adalah meningkatkan pemahaman dan pengetahuan kepada pengrajin tempe akan pentingnya penerapan Good Manufacturing Practices (GMP) dan keamanan pangan bagi produk agar dapat memperluas pasar usahanya. Adapun Mitra sasaran program pendampingan masyarakat ini adalah kelompok Perajin tempe di Kampung Tempe, Desa Beji Junrejo Kota Batu yang telah produktif secara ekonomi sebagai pengrajin Tempe. Adapun usaha yang akan dilakukan adalah edukasi kepada pengrajin tempe tentang kondisi sanitasi lingkungan, sarana dan prasarana produksi tempe serta hubungannya dengan proses produksi dan bahan baku yang digunakan apakah telah memenuhi syarat. Edukasi ini diharapkan adanya perubahan perilaku pengrajin dalam proses produksi. Metode yang digunakan adalah Participatory Action Research (PAR) berupa penyuluhan, demonstrasi serta pendampingan. Pendampingan dilakukan selama 3 bulan. Hasil pendampingan menunjukkan bahwa 95,00\% responden setuju bahwa kegiatan pengabdian masyarakat bermanfaat, 89,00\% responden setuju kegiatan edukasi ini sangat meningkatkan kualitas, $97.00 \%$ responden menyatakan ilmu bertambah setelah mengikuti pelatihan, dan $85.00 \%$ responden menyatakan bahwa keseluruhan kegiatan pelatihan sudah baik.
\end{abstract}

Kata Kunci: Beji-Batu, Good Manufacturing Practices (GMP), Keamanan Pangan, Tempe

\begin{abstract}
Tempe is a plant-based food product that has high nutritional value. In Beji village, Batu city is one of the centers for tempe craftsmen. The tempe produced is typical of the region, but the obstacles faced by the craftsmen have not implemented the importance of Good Manufacturing Practices (GMP) and food safety so that the resulting tempe is less constant. The existence of the potential of the tempe village, an educational program is carried out for the tempe craftsmen. The main objective in this mentoring program is to increase understanding and knowledge to tempe producers about the importance of implementing Good Manufacturing Practices (GMP) and food safety for products in order to expand their business market. The target partner of this community assistance program is a group of tempe craftsmen in the Tempe Village, Beji Junrejo Village, Batu City who have been economically productive as Tempe craftsmen. The business that will be carried out is to educate the tempe producers about the condition of environmental sanitation, facilities and infrastructure for tempe production as well as their relationship with the production process and whether the raw materials used meet the requirements. This education is expected to change the behavior of craftsmen in the production process. The method used is Participatory Action Research (PAR ) in the form of counseling, demonstrations and mentoring. Mentoring was carried out for 3 months. The results of the assistance showed that $95.00 \%$ of respondents agreed that community service activities were beneficial, $89.00 \%$ of respondents agreed that this educational activity greatly improved quality, $97.00 \%$ of respondents stated that their knowledge had increased after participating in training, and $85.00 \%$ of respondents stated that the overall training activities were good.
\end{abstract}

Keywords: Beji-Batu, Good Manufacturing Practices (GMP), Food Safety, Tempe 


\section{PENDAHULUAN}

Desa Beji merupakan salah satu pusat pengarajin tempe di Kota Batu. Tempe yang dihasilkan memiliki ke khasan rasa yang unik sehingga sering dibuat oleh oleh para wisatawan. Indonesia merupakan negara terbesar produsen tempe dan posisi tempe saat ini sedang diajukan sebagai warisan tak benda ke UNESCO, tentunya menjadi kebanggaan bangsa Indonesia bahwa tempe merupakan salah satu produk hasil karya anak bangsa yang patut diakui keberadaanya. Tempe sebagai makanan tradisional indonesia yang terbuat melalui proses fermentasi ini cukup diminati oleh setiap anggota keluarga bahkan menu ini hampir ada setiap hari karena nilai gizinya yang cukup tinggi setara dengan protein hewani. Tempe memiliki banyak manfaat di antaranya menurunkan flatulensi dan diare, menghambat biosintesis kolesterol dalam hati, mencegah oksidasi LDL, menurunkan total kolesterol dan triasilgliserol, meningkatkan enzim antioksidan SOD, dan menurunkan risiko kanker rectal, prostat, payudara, dan kolon.

Beji kota Batu merupakan produsen tempe terbanyak di kota batu dimana jumlah pengrajin tempe sebesar 122 orang. Salah satu pengrajin tempe yang sedang berkembang adalah Rizki Jaya di desa Beji milik Ibu Fikayati. Akan tetapi pengelolaan pengrajin tersebut kurang memperhatikan kebersihan lingkungan kerja saat melakukan proses produksi. Terlihat dari hasil pengamatan yang dilakukan, terdapat faktor yang mempengaruhi kebersihan dari produk tempe. Beberapa faktor tersebut adalah tata letak proses produksi, kebersihan lokasi, sarana-prasarana, sanitasi dsb. Kebersihan yang belum memadai dengan tidak ada fasilitas sanitasi serta baju produksi seperti alas kaki, masker, dan sarung tangan untuk pekerja saat memproduksi.

Salah satu kendala yang dihadapi oleh UMKM kampung tempe adalah tempe yang dihasilkan kurang stabil, jika terlalu panas maka tempe akan busuk jika terlalu dingin proses fermentasi akan berlangsung lama. Selain itu pengrajin kurang memperhatikan kebersihan alat yang digunakan, padahal kebersihan alat merupakan faktor utama yang menentukan kualitas produk. Hal ini terlihat dari tata letak lokasi pengolahan yang masih berdekatan dengan kandang, fasilitas sanitasi dan sarana dan prasarana yang kurang baik. Hal demikian akan menjadikan kualitas produk yang dihasilkan menjadi kurang baik. Good Manufacturing Practices (GMP) lingkup bangunan dan tenaga kerja sangat penting untuk diterapkan pada suatu industri dibidang pangan guna menghasilkan suatu produk yang aman dan layak untuk dikonsumsi.

Industri tempe di Beji, Kota Batu sebagian besar masih merupakan industri rumah tangga atau Usaha Kecil dan Menengah (UKM) yang dikerjakan secara tradisional, sehingga pengrajin masih mengikuti cara dan kebiasaan yang biasa dilakukan secara turun temurun. Namun ada hal hal tertentu yang diperlukan untuk menjamin agar tempe yang dihasilkan menjadi baik dan berkualitas hal ini dimulai dari prasyarat dasar atau penerapan GMP. Selama pengrajin tidak menerapkan prasyarat dasar maka mutu tempe tidak bertahan lama atau kurang konstan. Dengan penerapan GMP pada pengrajin tempe maka dapat memperluas pasar penjualan seperti supermarket atau toko toko besar. Untuk mendapatkan SPP-IRT terdapat beberapa aspek yang dinilai, antara lain lokasi dan lingkungan produksi, bangunan, fasilitas, peralatan, sanitasi, karyawan yang bekerja sesuai dengan peraturan Cara Produksi Pangan yang Baik untuk industri rumah tangga (CPBB-IRT) yang diatur oleh BPOM.

Tujuan pengabdian masyarakat ini adalah memberikan edukasi kepada pengrajin tempe tentang program dasar dan pentingnya keamanan pangan untuk industri tempe. Pengrajin belum memahami secara benar pentingnya prasyarat dasar dan keamanan pangan sehingga terkadang tempe yang dihasilkan kualitasnya kurang baik. Prasyarat dasar GMP tentang lingkup bangunan dan tenaga kerja ini bertujuan untuk memberikan tindakan perbaikan bagi pengrajin agar nantinya dapat menjamin kualitas dan keamanan produk tempe yang dihasilkan. Evaluasi GMP dilakukan dengan membandingkan standard sanitasi yaitu dengan menggunakan pedoman Peraturan Menteri Perindustrian Republik Indonesia No. 75/M-IND/PER/7/2010 tentang Pedoman Cara Produksi Pangan Olahan Yang Baik (Good Manufacturing Practice) yang terkait dengan pelaksanaan sanitasi bangunan dan tenaga kerja atau karyawan. Di pengrajin ini masih membutuhkan banyak perbaikan, terutama di lingkup bangunan seperti, sudut pertemuan dinding dan lantai, penggunaan pintu, jendela dan ventilasi serta penerangan lampu. Pada lingkup tenaga kerja, perbaikan yang seharusnya dilakukan meliputi, penggunaan seragam, masker, sarung tangan, sepatu dan hairnet. Dengan pendampingan ini diharapkan pengrajin lebih memahami dan mampu meningkatkan produktivitas produksi, menjadikan lingkungan kerja yang bersih, sehat, aman, nyaman sehingga mampu menciptakan kondisi berketahanan iklim. 


\section{METODE}

Dalam rangka mengubah kondisi penduduk desa Beji secara sosial, ekonomi dan lingkungan, akan digunakan metode Participatory Action Research (PAR). Metode ini dilakukan untuk memahamkan penduduk desa terhadap: (1) Potensi-potensi yang dimiliki dari pengelolaan tempe; (2) Keinginankeinginan untuk mengatasi kekurangan dan kelemahannya khususnya berkaitan dengan pengelolaan tempe; (3) menyusun strategi dan perbaikan pada proses produksi melalui edukasi dan pendampingan yang intens. Metode action research ini digunakan untuk tidak membuat penduduk dampingan sebagai obyek, tetapi menjadikannya sebagai subyek penelitian. Posisi peneliti lebih sebagai fasilitator bagi masyarakat untuk mencapai cita-citanya dan memberikan jalan keluar dalam merumuskan strategi yang dapat digunakan masyarakat untuk mencari jalan keluar bagi permasalahan mereka. Namun perumusan jalan keluar dan strategi ini tetap melibatkan penduduk dengan harapan apabila mengalami masalah sosial, ekonomi dan lingkungan atau lainnya mereka bisa memecahkan permasalahan mereka secara sendiri.

Prioritas program ini adalah penguatan program dasar atau yang biasa disebut Good Manufacturing Practices (GMP) edukasi dan Pendampingan dalam penerapan keamanan pangan. Metode Pelatihan untuk melaksanakan kegiatan tersebut digunakan beberapa metode pelatihan, yaitu:

a. Metode Ceramah

Metode ceramah dipilih untuk memberikan penjelasan tentang apa pentingnya dalam menerapkan program dasar untuk proses produksi melalui pendekatan cara pengolahan pangan yang benar (CPPB) atau Good Manufacturing Practices (GMP) terutama dalam hal tindakan pengendalian kondisi sanitasi dan higiene selama pelaksanaan proses produksi tempe.

b. Metode Tanya Jawab

Metode tanya jawab ini sangat penting bagi para pengrajin, baik di saat menerima penjelasan tentang program penerapan dasar, Metode ini memungkinkan pengrajin tempe menggali pengetahuan sebanyak-banyaknya tentang GMP dan keamanan pangan.

c. Metode Simulasi

Metode ini sangat penting diberikan kepada para pengrajin tempe untuk memberikan kesempatan mempraktekan cara pengolahan produksi sesuai GMP. Harapannya, pengrajin tempe akan benar-benar menguasai materi pelatihan yang diterima, mengetahui tingkat kemampuan dalam menerapkan keamanan pangan, kemudian mengidentifikasi kesulitan-kesulitan apa saja yang masih ada, sehingga dapat dipecahkan bersama.

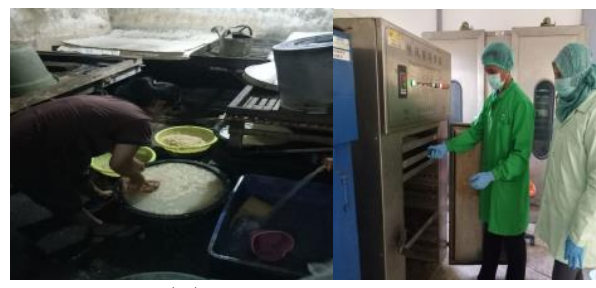

(a)

Sumber : Dokumen pribadi

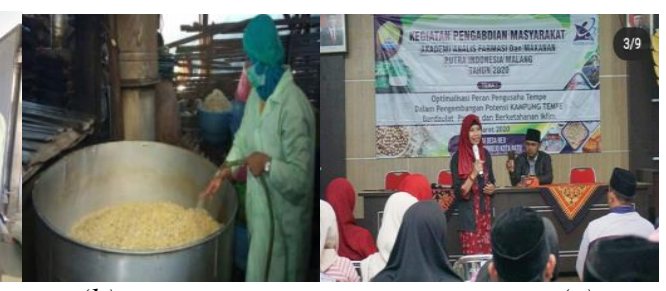

(c)

Gambar 1. a) Proses Pembuatan Tempe Tanpa Mengetahui GMP, b) Proses Pembuatan Tempe dengan GMP c) Sosialisasi

\section{HASIL DAN PEMBAHASAN}

Keamanan pangan saat ini menjadi perhatian penting dari bagian proses pengolahan pangan dimana pada kondisi pandemi keamanan pangan menjadi salah satu hal utama yang di cari oleh konsumen. Meskipun belum ada penelitian yang menyatakan bahwa virus Covid 19 tertular dari makanan namun pada saat ini keamanan pangan tetap menjadi hal utama. Termasuk salah satunya adalah tempe, salah satu jenis pangan penting dalam penyediaan sumber protein nabati masyarakat Indonesia. Namun, tempe merupakan bahan pangan yang mudah rusak. Daya tahannya 2-3 hari, lebih dari itu tempe akan rusak atau tidak layak dikonsumsi. Indonesia merupakan salah satu negara penghasil tempe terbesar di Asia bahkan didunia. Forum tempe Indonesia saat ini mendaftarkan tempe ke UNESCO sebagai warisan budaya bangsa non benda atau 'Intangible Cultural Heritage of Humanity. Melihat potensi yang cukup besar dari tempe di desa Beji bahkan disebut sebagai kampung tempe inilah yang dilakukan pada proses pendampingan pada pengrajin tempe di Desa Beji. Tempe adalah makanan tradisional yang dihasilkan 
dari fermentasi biji kedelai atau beberapa bahan lainnya. Fermentasi menggunakan beberapa jenis kapang Rhizopus, seperti Rhizopus oligosporus, Rhizopus oryzae, Rhizopus stolonifer, dan beberapa jenis kapang Rhizopus lainnya. Dimana pada proses fermentasi akan terjadi hidrolisis senyawa-senyawa kompleks menjadi sederhana, sehingga baik untuk dicerna. Tempe merupakan makanan yang kaya akan serat pangan, kalsium, vitamin B, dan zat besi Tempe selain sebagai alternatif untuk mencukupi kebutuhan protein, juga memiliki nilai obat seperti antibiotika untuk menyembuhkan infeksi, antioksidan untuk menangkap radikal bebas.

\section{Good Manufacturing Practices (GMP)}

Hasil pelaksanaan kegiatan pengabdian masyarakat di Desa Beji berupa proses pendampingan dalam memberikan pemahaman atau edukasi kepada pengrajin tempe agar proses produksi yang dilakukan memenuhi prasyarat dasar untuk pengolahan pangan yang baik. Dengan pendampingan ini maka pengabdi mengevaluasi sarana produksi pangan industri rumah tangga (IRT) pada olahan tempe. Melalui pemeriksaan Industri Rumah Tangga Pangan (IRTP) maka dapat meningkatkan kepercayaan konsumen terhadap produk pangan yang dihasilkan serta menumbuhkan kesadaran, motivasi produsen dan karyawan tentang pentingnya pengolahan pangan yang higienis dan tanggung jawab terhadap keselamatan konsumen (Badan POM, 2012). Dalam Peraturan Pemerintah Republik Indonesia No. 28 Tahun 2004 tentang Keamanan, Mutu dan Gizi Pangan, dijelaskan bahwa Produksi pangan adalah kegiatan atau proses menghasilkan, menyiapkan, mengolah, membuat, mengawetkan, mengemas, mengemas kembali, dan/atau mengubah bentuk pangan.

Adapun gambaran umum pengrajin tempe desa beji adalah sebagai berikut:

1. Pemeriksaan sarana produksi pangan olahan tempe dilakukan di Rumah Ibu Rizki yang berdomisili di RT03 RW 01 Beji. Pengrajin yang merupakan Binaan Akafarma ini telah menjalankan usahanya selama kurang lebih 10 tahun mulai beropersi tahun 2010. Kapasitas produksi tiap hari mencapai 250 kg kedelai. IRTP ini memiliki karyawan sebanyak 2 orang, dimana karyawannya belum dilatih atau diberikan pembekalan tentang hygiene, keamanan pangan pada proses produksi.

2. Hasil formulir pemeriksaan sarana produksi pangan industri rumah tangga ini menggunakan rumus total jumlah penyimpangan, seluruh hasil tiap-tiap standar dijumlahkan. Setelah hasil didapatkan maka dapat dilihat jumlah penyimpangan tersebut termasuk dalam level I, II, III, atau IV. Level tertinggi berada pada level I, sedangkan level terendah pada level IV. Semakin tinggi level yang didapat maka semakin kecil jumlah penyimpangan yang dilakukan oleh Industri tempe.

3. Dalam penentuan kategori ketidaksesuaian dalam industri rumah tangga pangan terdapat 4 penetapan ketidak sesuaian. Penetapan ketidaksesuaian tersebut terdiri dari $\mathrm{Mi}=$ minor, $\mathrm{Ma}=$ mayor, $\mathrm{Se}=$ serius, dan $\mathrm{Kr}=$ kritis. Hasil evaluasi kategori ketidaksesuaian yang ditemukan pada pengrajin tempe ini masuk pada level IV terdapat pada hasil SPPIRT, seperti disajikan pada Tabel 1.

Tabel 1. Penentuan Kategori Kesesuaian dan Ketidaksesuaian Dalam Industri Pangan

\begin{tabular}{|l|l|c|c|c|c|}
\hline \multirow{2}{*}{ No } & \multicolumn{1}{|c|}{ Elemen yang diperiksa } & \multicolumn{3}{c|}{ Ketidaksesuaian } \\
\cline { 3 - 6 } & & $\mathrm{Mi}$ & $\mathrm{Ma}$ & $\mathrm{Se}$ & $\mathrm{Kr}$ \\
\hline 1 & Lokasi dan lingkungan & & & & $\mathrm{V}$ \\
\hline 2 & Bangunan dan Fasilitas & & & $\mathrm{V}$ & \\
\hline 3 & Peralatan produksi & & & & \\
\hline 4 & Suplai air & & & $\mathrm{V}$ & \\
\hline 5 & Fasilitas dan kegiatan higiene dan sanitasi & & & & \\
\hline 6 & Kesehatan dan higiene karyawan & & & \\
\hline 7 & Pemeliharaan dan program higiene dan sanitasi & & & & \\
\hline 8 & Penyimpanan & & & & \\
\hline 9 & Pengendalian proses & & & & \\
\hline 10 & Pelabelan pangan & & & & \\
\hline 11 & Pengawasan oleh penanggung jawab & & & & \\
\hline 12 & Penarikan produk & & & & \\
\hline 13 & Pencatatan dan dokumentasi & & & & \\
\hline 14 & Pelatihan karyawan & & & \\
\hline
\end{tabular}


4. Pada point no 1 sd 8 adalah hal utama yang benar benar harus diperhatikan tetapi dari hasil pemeriksaan didapatkan 1 kritis dan 3 serius sehingga dibutuhkan pendampingan dan edukasi kepada pengrajin tempe. Hal ini dibutuhkan juga agar pangsa pasar penjualan UKM tempe bisa lebih luas sehingga program prasyarat dasar ini benar benar diterapkan.

\section{Keamanan Pangan Tempe}

Penerapan prinsip mutu dan keamanan pangan belum diimplementasikan oleh seluruh pengrajin tempe di desa Beji. Hal ini disebabkan masyarakat belum memahami pentingnya menerapkan keamanan pangan karena produk yang dihasilkan belum pernah ada kejadian yang dapat menyebabkan penyakit bahkan Kejadian Luar Biasa (KLB), sehingga dianggap produksi yang dilakukan selama ini aman. Penelitian Indrawati, dkk (2015) berupaya membuat model interaksi risiko dalam konteks rantai pasok dengan menggunakan metode Interpretive Structural Modeling and Analytical Network Process.

Upaya memetakan proses/aktivitas adalah hal yang penting untuk dilakukan agar proses/aktivitas yang ada secara keseluruhan dapat diketahui a. Pembelian bahan baku kedelai: Pembelian kedelai dilakukan melalui pemasok yang telah dikenal sehingga bahan yang diperlukan terjamin mutunya dengan baik. b. Pemeriksaan proses: Setiap proses yang dilakukan harus memenuhi syarat keamanan pangan artinya terhindar dari bahaya kimia, fisika dan biologi. Sebelum adanya edukasi pengrajin tempe tidak pernah memperhatikan hal ini. Air rendaman kedelai yang digunakan biasanya tidak dilakukan pengantian hingga sampai 4 hari sehingga berbau air ini yang biasanya disebut kecutan untuk proses fermentasi tempe secara alami c. Perawatan alat: Alat yang digunakan proses produksi hampir seluruhnya masih kotor dan berkarat, hal ini dibiarkan begitu saja karena pengrajin tidak paham benar akan pentingnya kebersihan alat. Dengan edukasi yang diberikan maka pengrajin dibantu untuk membersihkan alat alat yang digunakan agar tidak berkarat. Kebanyakan alat ini adalah penggiling kedelai, bak perendaman dan perebusan. d. Pengolahan: Ketika proses pembuatan tempe alur tidak sesuai (semrawut) hal ini memudahkan terjadinya kontaminasi oleh mikroorganisme dan bahan lain yang berbahaya. Dengan edukasi yang diberikan maka alur proses dibuat tertata sesuai desain pengolahan ( pemilihan kedelai, pencucian, perebusan, pendinginan dan fermentasi) alur ini dibuat tertata .Waktu yang diperlukan untuk mengolah tempe adalah 3 sampai 4 hari. Berikut adalah gambar perbedaan sebelum dan sesudah pendampingan.

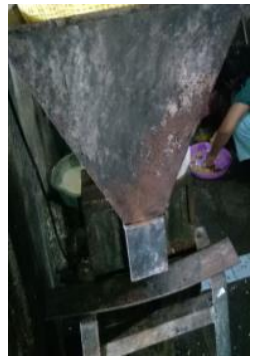

A-1

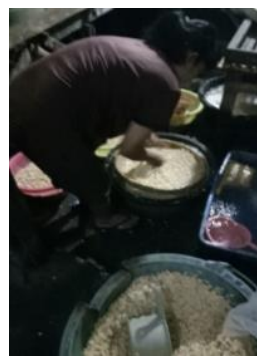

A-2

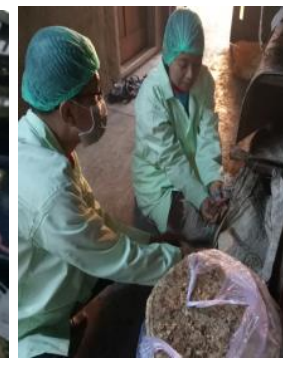

B-1

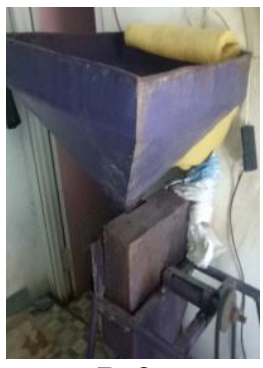

B-2

Gambar 2. [A-1],[A-2] Kegiatan Sebelum Pendampingan, [B-1],[ B-2] Sesudah Pendampingan

\section{Evaluasi kegiatan}

Hasil evaluasi dalam kegiatan program pengabdian masyarakat ini menggunakan dua pendekatan yaitu internal dan eksternal. Pendekatan eksternal dengan mangajukan pertanyaan melalui kuisioner tertutup yang disebarkan kepada pengrajin tempe binaan, Sedangkan pendekatan internal dengan melakukan pengamatan dan menganalisa kekurangan dan kebutuhan yang belum terpenuhi selama kegiatan berlangsung. Evaluasi dilakukan oleh tim pelaksana pengabdian masyarakat guna memberikan pelayanan yang maksimal. Adapun hasil kegiatannya disajikan pada Gambar 3.

Berdasarkan Gambar 3, Evaluasi pelatihan dapat disimpulkan bahwa 95,00 \% responden setuju bahwa kegiatan pengabdian masyarakat bermanfaat, $89,00 \%$ responden setuju kegiatan pendampingan UKM tempe berkualitas, $97.00 \%$ responden setuju bahwa ilmu bertambah setelah mengikuti pelatihan, dan $85.00 \%$ responden menyatakan bahwa keseluruhan kegiatan pelatihan sudah baik. Keseluruhan kegiatan yang dimaksud meliputi fasilitas yang diberikan, penyediaan materi dan pemateri pendampingan. Menjadi catatan kami dari hasil kuisioner yang disebar adalah tingkat pendidikan pengrajin tempe beragam. Tingkat pendidikan sangat berpengaruh terhadap keinginan untuk melakukan inovasi dan terobosan dalam memajukan sumber daya manusianya. Perlu pendekatan dan bertahap dalam menyampaikan materi sesuai dengan responden yang di hadapi. 


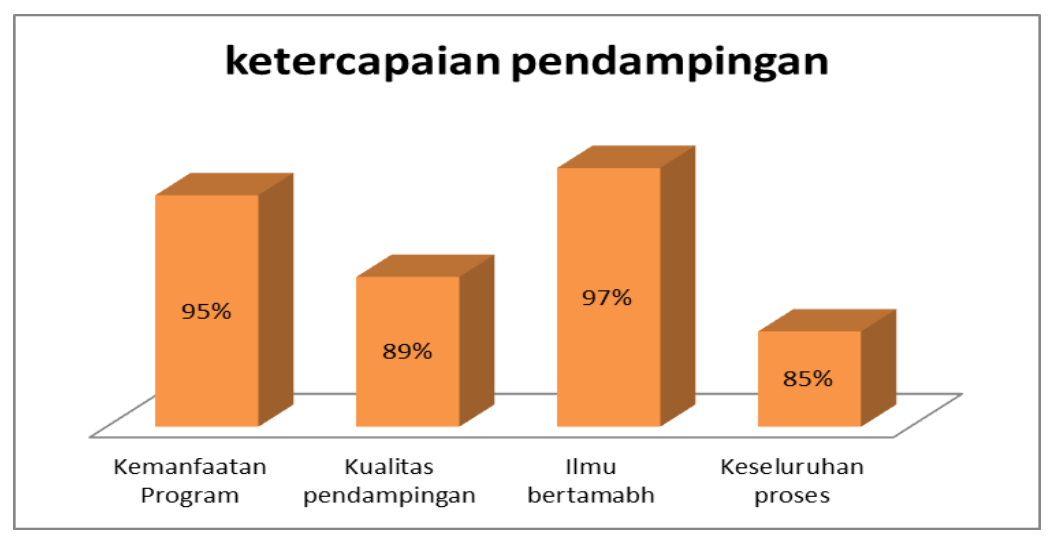

Gambar 3. Hasil Kuesioner Pendampingan

\section{SIMPULAN}

Berdasarkan hasil pelaksanaan kegiatan pengabdian kepada masyarakat, maka dapat disimpulkan edukasi dan pendampingan program prasyarat dasar dan keamanan pangan menunjukkan bahwa $95,00 \%$ responden setuju bahwa kegiatan pengabdian masyarakat bermanfaat, 89,00\% responden setuju kegiatan edukasi ini sangat meningkatkan kualitas produksi, $97.00 \%$ responden menyatakan ilmu bertambah setelah mengikuti pelatihan, dan $8500 \%$ responden menyatakan bahwa keseluruhan kegiatan pelatihan sudah baik.

\section{SARAN}

Perlu dukungan dari pemerintah kota terkait program pendampingan keamanan pangan secara intens tidak hanya pada UKM tempe tetapi juga pada UKM lain yang ada di kota Batu mengingat kota Batu adalah destinasi wisata.

Melihat hasil edukasi yang dapat meningkatkan kualitas produksi pada UKM maka diperlukan kemudahan bagi pengrajin tempe dalam proses pengurusan PIRT untuk produknya.

\section{UCAPAN TERIMA KASIH}

Terima kasih kepada warga desa Beji, Kota Wisata Batu yang sangat membantu dan mensuport kegiatan ini. Serta kepada AKAFARMA Putra Indonesia Malang dan Yayasan Putera Indonesia Malang.

\section{DAFTAR PUSTAKA}

Warisno dan Kres D. 2010. Meraup Untung dari Olahan Kedelai. Jakarta: PT. Agromedia Pustaka.

Indri astiansari, Anggoro Cahyo Sukartiko. 2014. Penerapan good manufacturing practices (gmp) lingkup bangunan dan tenaga kerja di industri tempe muchlar. Tugas Akhir D3 agro industri. Universitas Gadjah Mada Jogyakarta.

Diah Rachmi Damarasri, Sri Gunani Partiwi, dan Janti Gunawan. 2016. Penerapan Good Manufacturing Practice dan Work Improvement In Small Enterprise pada Usaha Kecil dan Menengah Untuk Pemenuhan Standar Kesehatan . Jurusan Teknik Industri, Fakultas Teknologi Industri, Institut Teknologi Sepuluh Nopember (ITS)

Steinkraus, K.H., 1983. Indonesian Tempeh and Related Fermentation. Dalam : Handbook of Indigenous Fermented Foods, ed. K.H., Steinkraus dkk. Marcel-Dekker Inc., NY. Hal 1-94.

Agosin E., D. Diaz, R. Aravena, and E. Yanez, 1989. Chemical and Nutritional Characterization of Lupine Tempeh. Journal of Food Science, Volume S4, No.1, University of Food Science. Chile.

Wijaya, C.H, Siti Nurjanah dan Qabul Dinanta Utama. 2015. Implementasi dan Analisis Keuntungan Teknologi Back-Slopping pada Pembuatan "Quick Tempe” Skala Industri Rumah Tangga. Jurnal Pangan, Vol. 24 No. 1 hal : 49-62

Babu D, Bhakyaraj \& Vidhyalaksmi.2009. A low cost Nutritious Food "Tempeh". Journal Of Dairy \& Food Science 4(1): 22-27P.

Indrawati, C.D.; Karningsih, P.D.; Vanany, I. (2015). "Development of supply chain risks interrelationships model using interpretive structural modeling and analytical network process". IPTEK Journal of Proceedings Series, Vol. 1, pp.: 449 - 453. 